\title{
Consideration on Cognition of Interactive Language Teaching_—Based on Analysis of Teaching Environment of College Foreign Language
}

\author{
XU Ruiyang \\ Shandong Polytechnic College, Jining, Shandong 272067 China \\ 545262418@qq.com
}

Keywords: university English; interactive teaching; theoretical principle; context; channel

\begin{abstract}
Interactive teaching is centralized on students, teachers should use language, acquisition and teaching theory as instruction, meanwhile adopt method of interaction by means of proposing questions according to self-characteristic, individual difference and teaching context of learners, actively activate learning initiative of students by teaching ways such as interactive and different group activates etc., so that form teaching channel interacts with teaching practice, interaction between students and teachers.
\end{abstract}

\section{Introduction}

With the gradual expansion and deepening of English teaching reform in university, its teaching model is taking place of huge changes: it changes from the single class teaching model focuses on traditional teachers lecturing to interactive teaching model focuses on students. Interactive English teaching uses students as the main body and it conforms to teaching target proposed by university English teaching reform, it is being implemented and popularized in more and more universities.

\section{Countermeasure application principle to implement analysis and discussion}

\section{A. Problems exist in group cooperative learning}

When teachers are organizing foreign language activities, they mostly use method of group cooperative learning to organize cooperative learning, or they adopt independent task way. In this process, students drawing a copy of $2^{\text {nd }}$ thinking map on the exercise book, they still use help letter as center and send out curve to outside. The structure is indicated by the following figure:

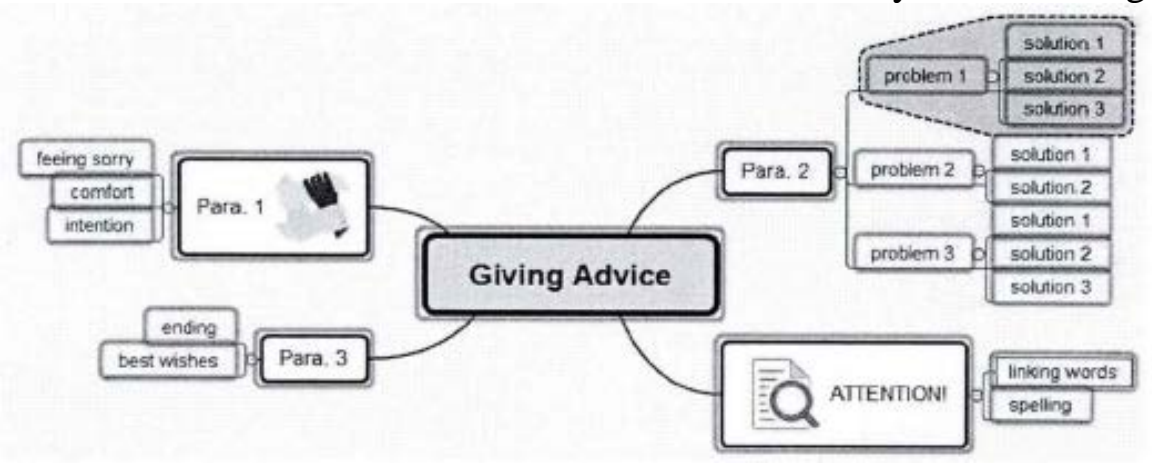

Figure 1 Thinking map of writing 


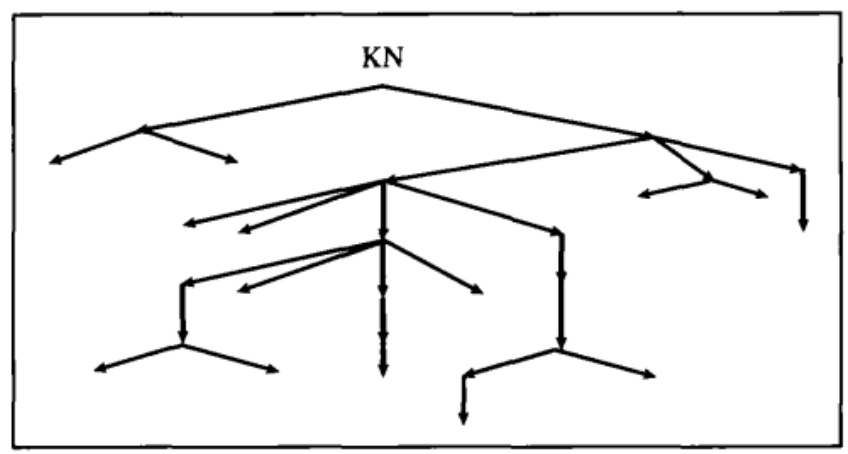

Figure 2 Structure diagram of example text

Students use text tree structure diagram formed by corpus marked information (please see figure 2), it combines with core topic to form macro impression.

\section{B. Analysis on material environment of foreign language class in China}

This paper makes analysis according to university class teaching condition in China, we observed that the number of students having big class in university reaches above 100 . According to survey, it indicates that when most students are implementing group activity, they do not implement interactive learning, which causes huge decrease in learning effect.

\section{Making analysis on low effect in class group cooperative learning and proposing} solution measures

This paper pays close attention to teaching strategy correlation in interactive language teaching, while low learning effect of group cooperative leaning is related to teaching strategy of teachers, they are gradually seeking errors and flaws occur in teaching, they timely make up their shortages and gradually enhancing target language teaching quality in the advancement process.

\section{Result analysis and discussion of interactive language teaching cognition under university foreign language teaching environment}

A. Test result comparison, analysis and discussion before and after interactive language teaching and cognition under university foreign language teaching environment

According to grading standard of college entrance examination, the number of students before and after writing result in this 5 levels and 0 marks respectively accounts for the following percentage:

Table 1 The distribution number and percentage of student writing before and after text

\begin{tabular}{|c|c|c|c|c|c|c|c|c|c|c|c|c|}
\hline $\begin{array}{l}\text { test } \\
\text { level }\end{array}$ & $\begin{array}{l}\text { very } \\
\text { the fif } \\
21-25\end{array}$ & $\begin{array}{l}\text { od in } \\
\text { level } \\
\text { larks }\end{array}$ & $\begin{array}{c}\text { clear } \\
4^{\text {th }} \\
16-20\end{array}$ & $\begin{array}{l}\text { the } \\
\text { el } \\
\text { arks }\end{array}$ & $\begin{array}{r}\text { just s } \\
\text { the } \\
\text { le } \\
11-1\end{array}$ & $\begin{array}{l}\text { o in } \\
\text { rd } \\
\text { arks }\end{array}$ & $\begin{array}{l}\text { bad } \\
\text { seco } \\
6-10\end{array}$ & $\begin{array}{l}\text { the } \\
\text { evel } \\
\text { arks }\end{array}$ & $\begin{array}{r}\text { very } \\
\text { the fi } \\
1-5\end{array}$ & $\begin{array}{l}\text { din } \\
\text { level } \\
\text { ks }\end{array}$ & unkn & vn 0 \\
\hline \multirow[t]{2}{*}{$\begin{array}{l}\text { befor } \\
\text { e test }\end{array}$} & $\begin{array}{l}\text { the } \\
\text { num } \\
\text { ber } \\
\text { of } \\
\text { peopl } \\
\text { e }\end{array}$ & $\begin{array}{l}\text { perce } \\
\text { ntage }\end{array}$ & $\begin{array}{l}\text { The } \\
\text { num } \\
\text { ber } \\
\text { of } \\
\text { peopl } \\
\text { e }\end{array}$ & $\begin{array}{l}\text { perce } \\
\text { ntage }\end{array}$ & $\begin{array}{c}\text { The } \\
\text { num } \\
\text { ber } \\
\text { of } \\
\text { peopl } \\
\text { e }\end{array}$ & $\begin{array}{l}\text { perce } \\
\text { ntage }\end{array}$ & $\begin{array}{c}\text { The } \\
\text { num } \\
\text { ber } \\
\text { of } \\
\text { peopl } \\
\text { e }\end{array}$ & $\begin{array}{l}\text { perce } \\
\text { ntage }\end{array}$ & $\begin{array}{c}\text { The } \\
\text { num } \\
\text { ber } \\
\text { of } \\
\text { peopl } \\
\text { e }\end{array}$ & $\begin{array}{l}\text { perce } \\
\text { ntage }\end{array}$ & $\begin{array}{c}\text { The } \\
\text { num } \\
\text { ber } \\
\text { of } \\
\text { peopl } \\
\text { e }\end{array}$ & $\begin{array}{l}\text { perce } \\
\text { ntage }\end{array}$ \\
\hline & 0 & 0 & 6 & $5.4 \%$ & 31 & $\begin{array}{c}27.7 \\
\%\end{array}$ & 49 & $\begin{array}{c}43.8 \\
\%\end{array}$ & 16 & $\begin{array}{c}14.3 \\
\%\end{array}$ & 10 & $8.9 \%$ \\
\hline $\begin{array}{c}\text { after } \\
\text { test }\end{array}$ & 0 & 0 & 19 & $17 \%$ & 54 & $\begin{array}{c}48.2 \\
\% \\
\end{array}$ & 22 & $\begin{array}{c}19.6 \\
\%\end{array}$ & 14 & $\begin{array}{c}12.5 \\
\%\end{array}$ & 3 & $2.7 \%$ \\
\hline
\end{tabular}

From the above table we can see that there are none students reach the fifth level of writing standard, but the number of students reaching the fourth level increases from 6 to 19, it totally increases 13 students, which is the 3 times of students number before test, the number of students reaches the third level increases from 31 to 54 before test, it totally increases students, which is 1.7 times of student number before test, the number of students in the second level decreases from 49 to 
22 , it totally decreases 27 students; the number of students in the first level and 0 level respectively decreases 2 students and 7 students. From the above data we can see that writing of interactive teaching under support of thinking map in the first semester, which makes student number between 0 and 10 marks decreases from 75 before test to 39 after test, from this it can be seen that interactive teaching model under support of thinking map, writing marks of $1 / 3$ students enhances one level on the original basis.

The highest mark and average mark of students before and after test

\begin{tabular}{|c|c|c|}
\hline & before test & after test \\
\hline the highest mark & 17 & 18 \\
\hline the average mark & 8.72 & 11.06 \\
\hline
\end{tabular}

From the above table we can see that the highest mark has little change before and after test, but the average mark increases by 2.34marks after test than that of before test. By combining with data analysis in the table 1 and table 2, it can be regarded that the overall mark of students is far higher than that of students before test.

Table 3 The highest mark and average mark before and after test of higher class

\begin{tabular}{|c|c|c|}
\hline & before test & after test \\
\hline the highest mark & 18 & 20 \\
\hline the average mark & 8.39 & 10.38 \\
\hline
\end{tabular}

By combining with table 2 and table 3 we can see that the highest mark of test class is lower than that of all classes in the higher grade, but the average mark of test class after test increases by 2.34 marks than that of after test, which increases by 1.99 marks than that of higher class. The application effect of interactive teaching model is much more effective than that of traditional English writing and teaching model.

\section{B. Questionnaire result analysis and discussion of interactive language teaching cognition under university foreign language teaching environment}

Before test is formally started, this paper sends out questionnaire to 112 students of 2 classes to implement test, the recovery rate is $100 \%$. This questionnaire is sending out in class, the following is the detailed analysis on 112 pieces of questionnaire.

Table 4 Survey result data statistics and percentage of students writing attitude

\begin{tabular}{|c|c|c|}
\hline \multirow{2}{*}{ Questions } & \multicolumn{2}{|c|}{ Survey result data statistics and percentage of students writing attitude } \\
\hline & Option & Survey result percentage \\
\hline \multirow{6}{*}{$\begin{array}{l}\text { 1. What about your } \\
\text { secondary school } \\
\text { entrance examination } \\
\text { in which section(full } \\
\text { score is } 120 \text { ) }\end{array}$} & A. 110(included)-120 & $3.5 \%$ \\
\hline & B. 100(included)-110 & $10.7 \%$ \\
\hline & C. 90(included) -100 & $15.1 \%$ \\
\hline & D. 80(included)-90 & $16.9 \%$ \\
\hline & E. 70(included)-80 & $18.8 \%$ \\
\hline & G. 70以下 & $34.9 \%$ \\
\hline \multirow{3}{*}{$\begin{array}{l}\text { 2. Do you think English } \\
\text { writing is difficult? }\end{array}$} & A.difificult & $61.6 \%$ \\
\hline & B.common & $27.6 \%$ \\
\hline & C. easy & $10.7 \%$ \\
\hline \multirow{3}{*}{$\begin{array}{l}\text { 3. Do you think English } \\
\text { writing is interesting or } \\
\text { not? }\end{array}$} & A. very interesting & $4.5 \%$ \\
\hline & B.common & $39.2 \%$ \\
\hline & C. uninteresting & $56.2 \%$ \\
\hline \multirow{3}{*}{$\begin{array}{l}\text { 4. Do you afraid of } \\
\text { English writing? }\end{array}$} & A. very afraid & $24.1 \%$ \\
\hline & B. common & $43.8 \%$ \\
\hline & C. not afraid & $32.1 \%$ \\
\hline
\end{tabular}

From the above data we can see the excellent students are very few among 112 students in these 2 classes, there are 16 students above 100 scores, which only accounts for $4.2 \%$, the students with bad base accounts for larger percentage, the percentage of students below 80 scores reaches 53.7\%(60 students), teaching tasks in English has a long way to go. Of which, there are 61.6 \%( 69 students) think English is very difficult, meanwhile there are $56.2 \%$ ( 63 students) do not like 
English teaching, there are even 24.1 \%( 27 students) are afraid of English writing. These data indicates most students regard English teaching as one difficult thing, we should help students to enhance interest.

Table 5 Survey result data statistics and percentage of students in English writing process

\begin{tabular}{|c|c|c|}
\hline \multirow[t]{2}{*}{ questions } & \multicolumn{2}{|c|}{$\begin{array}{l}\text { Survey result data statistics and percentage of students writing } \\
\text { attitude }\end{array}$} \\
\hline & Option & survey result percentage \\
\hline \multirow{2}{*}{$\begin{array}{l}\text { 5. Do you carefully read } \\
\text { questions and consider writing } \\
\text { structure before writing? }\end{array}$} & A. Yes & $36.6 \%$ \\
\hline & B. No & $63.4 \%$ \\
\hline \multirow{4}{*}{$\begin{array}{l}\text { What about your writing steps } \\
\text { in usual writing? }\end{array}$} & $\begin{array}{l}\text { A. firstly collect relevant } \\
\text { writing material and then list } \\
\text { outline finally start writing. }\end{array}$ & $2.7 \%$ \\
\hline & $\begin{array}{l}\text { B. Generally list one outline } \\
\text { and then start writing }\end{array}$ & $42.9 \%$ \\
\hline & $\begin{array}{c}\text { C. directly write without } \\
\text { outline, translate their ideas into } \\
\text { English }\end{array}$ & $48.2 \%$ \\
\hline & D. others & $6.3 \%$ \\
\hline \multirow{3}{*}{$\begin{array}{l}\text { 7. Do you know how to collect } \\
\text { writing material? }\end{array}$} & A Yes & $40.1 \%$ \\
\hline & B. Know a little & $47.3 \%$ \\
\hline & C. completely unknown & $12.5 \%$ \\
\hline \multirow{3}{*}{$\begin{array}{l}\text { 8. Do you know how to list } \\
\text { outline before writing? }\end{array}$} & A. yes & $9.8 \%$ \\
\hline & B know a little & $59.8 \%$ \\
\hline & C.completely unknown & $30.4 \%$ \\
\hline \multirow{3}{*}{$\begin{array}{l}\text { 9. Do you know how to enrich } \\
\text { composition content? }\end{array}$} & A. yes & $2.7 \%$ \\
\hline & B. know a little & $40.1 \%$ \\
\hline & C. completely unknown & $57.1 \%$ \\
\hline
\end{tabular}

The above questions make survey on English teaching problems of their own, there are 36.6\% students (41 students) carefully read question and consider writing structure before writing. On considering writing structure, there are $59.8 \%$ ( 67 students) know a little on how to list outline, while there are $30.4 \%$ ( 34 students) completely unknown on how to list outline and directly start writing, they translate their Chinese thinking ideas into English.

\section{Conclusions}

In class teaching, students go out from the virtual and simulated world and go into the real interpersonal context, they use language by ways of listening, speaking, answering questions, participating in discussion, meaning negotiation etc to exercise their thinking initiative and logic precision, which paves base for effective written communication. Writing is the cognition process of meaning construction and expression; it is the process of interactive operation between comprehension and expression. At the same time of exercising language application ability of writers, it also cultivates their thinking ability and test ability. As for composition from students, we should timely give result grading and diction, syntax etc and correct it, which can greatly increase their learning initiative and activate their learning fighting spirit. Positive emotion such as active participation and correction is the effective channel to enhance precise expression. The research result indicates that ACT plan based on principle of interactive language teaching can effectively accelerate writing ability of students, which is worthwhile for further improvement and popularization. 


\section{References}

[1]Nie Shaofeng. Illumination of America ESL Teaching Course Characteristic on Foreign Teaching in China [J]. Journal of Agricultural University of Shenyang (social and science edition), 2017, 19(05):590-594.

[2]Wu Ying, Teng Yumei. Construction Elements of Applicable and Interactive College Teaching Model [J]. Journal of Changchun University, 2012, 22(02):230-232.

[3] Yu Xuan. Constructing Interactive Teaching Model [J]. Journal of Tongren Institute, 2012, 14(04):121-123.

[4]Zhou Huiqing, Zhou Yonghong. Positioning of Teachers Role of Interactive Teaching under Network Environment [J]. Journal of Changsha Railway Institute (social and science edition), 2009, 10(01):231-232+241.

[5] Zhang Fang. Discussion on Student Participation in Interactive College English Class [J]. Education and Career, 2009(26):97-99. 